\title{
Impacts of abrupt temperature changes and warming hiatuses on water resources in the mid- and-low-latitude regions of the temperate continental-monsoon transition zone
}

\author{
Xing Huang \\ Inner Mongolia Agricultural University \\ Long Ma ( $D$ malong4444333@163.com ) \\ Inner Mongolia Agricultural University \\ Tingxi Liu \\ Inner Mongolia Agricultural University \\ Bolin Sun \\ Inner Mongolia Agricultural University \\ Yang Chen \\ Inner Mongolia Agricultural University \\ Zixu Qiao \\ Inner Mongolia Agricultural University
}

\section{Research Article}

Keywords: abrupt temperature change, warming hiatus, water resources, quantitative impact

Posted Date: February 24th, 2022

DOI: https://doi.org/10.21203/rs.3.rs-1391791/v1

License: (c) (i) This work is licensed under a Creative Commons Attribution 4.0 International License.

Read Full License 


\title{
Impacts of abrupt temperature changes and warming hiatuses on water resources in the mid-and-low-latitude regions of the temperate continental-monsoon transition zone
}

\author{
Xing Huang ${ }^{1}$ (Submit the author), Long $\mathrm{Ma}^{1}{ }^{*}$ ( corresponding author), Tingxi Liu' ${ }^{1}$, Bolin Sun ${ }^{1}$, Yang Chen ${ }^{1}$, Zixu Qiao ${ }^{1}$ \\ 1 College of Water Conservancy and Civil Engineering College, Inner Mongolia Agricultural University, Hohhot \\ 010018, China. \\ *Correspondence: malong4444333@163.com; Tel.: +86-1880-471-6707 \\ Received: ; Accepted: ; Published:
}

Abstract: The global climate has undergone significant changes in the past 100 years, yet the extent to which abrupt temperature changes (ATCs) and warming hiatuses (WHs) impact runoff remains unclear. This study used the water balance model (WBM) to quantitatively assess the impacts of climate change and human activities on the measured runoff at representative runoff stations in the mid-and-low-latitude regions of the temperate continental-monsoon transition zone and further analysed the impacts of ATCs and WHs on the runoff at the representative stations. The results show the following. The runoff in the study area decreased overall, and the runoff at five stations located in the northeast and west was essentially not impacted by human activities, while the runoff at seven stations in the central part of the study area was significantly impacted by human activities, with a maximum degree of impact of more than $70 \%$. The average temperature of each basin in the study area underwent a significant abrupt increase in the 1990s, which had a negative driving effect on runoff, reducing the runoff depth by 1.92-2.98 $\mathrm{mm}$. The runoff between Hailar and Halaqin in the central part of the study area was significantly impacted by human activities, with a maximum degree of impact of more than $70 \%$. After removing the impact of human activities, evaporation tended to decrease after the abrupt temperature increase; i.e., an "evaporation paradox" phenomenon occurred in these regions. During this period, the amount of precipitation was stable, and the ATC increased the runoff by $0.27-11.74 \mathrm{~mm}$; the runoff changes at the Yingluoxia and Zhengyixia stations in the west were only slightly impacted by human activities, and the ATC significantly increased the runoff, which reached $13.86 \mathrm{~mm}$. In 2007, the average temperature in some basins experienced a WH, which had a relatively small impact on the runoff and a negative driving effect, reducing the runoff by 0.13 $5.19 \mathrm{~mm}$. In terms of the contribution to runoff changes around the ATC and WH, the contribution of temperature to runoff changes after the ATC was slightly greater after than that before the ATC, while the contribution of temperature to runoff changes before and after the WH did not exhibit a clear variation pattern.

Keywords: abrupt temperature change; warming hiatus; water resources; quantitative impact 
The global temperature has undergone a significant abrupt change since the 20th century (Huang et al., 2020). After 1998, the temperature increased at a rate close to 0 and even declined slightly in some regions, resulting in a warming hiatus (WH) (Zhang et al., 2019). Drastic climate changes impact regional river runoff and water resources, leading to an increasing conflict between regional water supply and demand (Zhao et al., 2014). However, the extent to which abrupt temperature change (ATCs) and WHs impact water resources is still unclear.

Influenced by the changing environment, approximately one-third of the top 200 large rivers in the world are significantly changing, with 19 rivers showing significant increases and 45 showing significant decreases, and both human activities and climate change have a large impact on runoff (Dai, 2009). In China, the measured runoff in 1970-2010 was 30-70\% lower than that in 1950-1969 (Zhang, 2017; Zhang, 2007). The measured runoff in the Liaohe River Basin and the Songhua River Basin in northern China has significantly decreased since the 1970s (Wang, 2017; Tian, 2018). Under the changing environment, the runoff of the upper reaches of the Yellow River has a slightly decreased, while that of the middle and lower reaches has significantly decreased (Zhao, 2018). A great number of large reservoirs have been constructed in the upper reaches of the Yangtze River, the largest river in China, exerting an enormous impact on the river runoff in the middle and lower reaches and leading to an earlier runoff season and a significant decrease in flow in summer and autumn (especially in October) (Zhou, 2018). The measured runoff of the Xijiang River, the largest tributary of the Pearl River in southern China, decreased remarkably from 1950 to 2015, with a strong continuity (Chen, 2018). Recent observations and existing studies suggest that river runoff in China has changed substantially in the past 50-60 years, posing new challenges to water resources management (Wang et al., 2006).

Three main types of methods have been used in recent studies to assess the causes of runoff changes, namely, general statistical models, coupled hydrothermal models, and hydrological models (Yang et al., 2014), while most studies of the impacts of climate change on runoff have been based on three methods, namely, the empirical statistical method, the elasticity coefficient method (Liu et al., 2016) and the hydrological model (WANG X. 2014). Previous studies have yielded fruitful findings. For example, runoff changes in West Africa have been shown to be closely related to changes in precipitation, and potential evapotranspiration has been shown to have a small impact on runoff (Roudier et al., 2014). Changes in forest cover in the Boca Basin of Slovakia have led to major changes in runoff (Labat et al., 2020). The decrease in the frost depth in the Volga Basin of Russia has led to an average increase of $17 \%$ in winter runoff (Kramer et al., 2015). In the Buqtyrma Basin 
of Kazakhstan, human activities have had a much greater impact on runoff changes in the lower reaches than in the middle and upper reaches, with a contribution of $84.66 \%$ (Rakhimova et al., 2020). A study of the Mediterranean region found that temperature increases have accelerated snowmelt in mountainous areas, eventually leading to a decrease in summer runoff and an increase in winter runoff, and the annual runoff has decreased substantially as the temperature has increased (Mimikou et al., 2000). In the Great Lakes region of the United States, precipitation and runoff have decreased to onefourth and one-half of their original levels, respectively, and the increased levels of greenhouse gases (e.g., carbon dioxide) in the air have led to a substantial increase in runoff(Idso et al., 1987). In China, precipitation changes and potential evapotranspiration in the Sanjiangyuan region have played positive and negative roles in driving runoff changes, respectively (Zhang et al., 2011); precipitation changes in the Yellow River Basin have been the most influential factor on natural runoff changes (Fang et al., 2014), and underlying surface changes have played a dominant role in the reduction of runoff in most subbasins (Yang et al., 2015); due to the construction of large-scale water conservancy projects in the Haihe River Basin in the mid- to late-1960s, human activities have been responsible for as much as 60-80\% of runoff changes (Zhang et al., 2017); human activities in the Wuding River Basin have been the dominant factor for runoff changes, on which vegetation growth has a strong moderating effect (Yang et al., 2017); the contributions of climate change, underlying surface change, and human activities to runoff changes in the middle and upper reaches of the Huaihe River Basin are $37.13 \%,-53.53 \%$, and $-9.34 \%$, respectively, and underlying surface change is the main cause of runoff reduction (Yin et al., 2018).

In summary, numerous studies have been conducted on the characteristics and attribution of runoff changes, and many researchers have carried out attribution analysis on runoff changes in major river basins in China (Rakhimova et al., 2020). While studies have focused on human activities and climate change, some researchers have also evaluated the degree of influence of factors such as precipitation and evaporation on runoff (Roudier et al., 2014), but information on the degree of influence of ATCs and WHs on runoff is limited. Thus, what are the impacts of ATCs and WHs on water resources, after highly influential factors such as human activities and precipitation are removed? Accordingly, can the significant increase or decrease in runoff be explained when precipitation tends to be stable? To answer these questions, this study selected the mid-and-low-latitude regions of the temperate continental-monsoon transition zone with a large east-west span as the study object. Monthly runoff data from 12 representative runoff stations were used to quantitatively analyse the impacts of sudden temperature changes and WHs on runoff. The results from this study can help elucidate the mechanism of interaction between climate change and the hydrological cycle, and thus, this study has scientific significance and practical implications. 


\section{Overview of the study area, data and methods}

\subsection{Overview of the study area}

The study area included the mid-and-low-latitude regions of the temperate continental-monsoon transition zone located in the northern border of China (Figure 1), including the Inner Mongolia Autonomous Region and Gansu Province, with a straight-line distance of more than 2,400 km from east to west and a span of more than $1,700 \mathrm{~km}$ from north to south. The study area covers the second largest plateau in China and includes a vast territory, stretching from the Xing'an Mountains in the east to the foot of the Qilian Mountains in the west and spanning Northeast, North, and Northwest China.

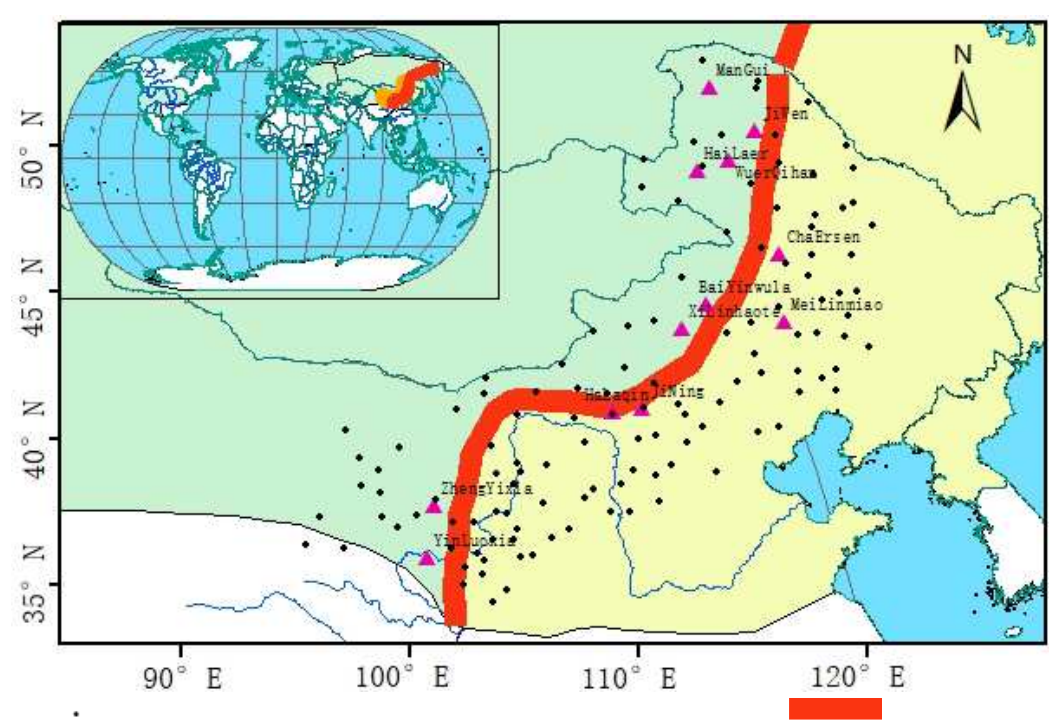

Figure 1 Location of the study area, runoff and meteorological stations

\subsection{Data sources}

Twelve representative hydrological stations (Mangui, Jiwen, Wuerqihan, Hailar, Chaersen, Baiyinwula, Xilinhot, Meilinmiao, Jining, Halaqin, Yingluoxia, and Zhengyixia) with complete longterm series of actual measurements were selected to represent the hydrological regime of the midand-low-latitude regions of the temperate continental-monsoon transition zone. The data were obtained from the compiled information of local hydrological bureaus. Table 1 lists the basic information of the 12 representative hydrological stations. In addition, 98 meteorological stations in and around the study area were selected (Figure 1). Average monthly temperature, precipitation, and evaporation data at these stations from the time of their establishment until 2018 were obtained from the compiled information of the Data Center of China Meteorological Administration (http://data.cma.cn/). The data were tested, and no obvious abrupt change points or random changes were found in the various types of meteorological data at each station, the data changes were relatively uniform and consistent, and the data were reliable. 
Table 1 Hydrological characteristics of representative stations

\begin{tabular}{|c|c|c|c|c|c|c|c|}
\hline ID & River & $\begin{array}{l}\text { Hydrological } \\
\text { station }\end{array}$ & $\begin{array}{l}\text { Basin area } \\
\left(\mathrm{km}^{2}\right)\end{array}$ & $\begin{array}{c}\text { Annual } \\
\text { precipitation } \\
(\mathrm{mm})\end{array}$ & $\begin{array}{c}\text { Average } \\
\text { annual } \\
\text { temperature } \\
\left({ }^{\circ} \mathrm{C}\right)\end{array}$ & $\begin{array}{c}\text { Annual } \\
\text { runoff } \\
\text { depth }(\mathrm{mm})\end{array}$ & Data series \\
\hline 1 & $\begin{array}{c}\text { Songhua River } \\
\text { Basin }\end{array}$ & Mangui & 7711 & 447.04 & -3.98 & 85.15 & $1973-2018$ \\
\hline 2 & $\begin{array}{c}\text { Songhua River } \\
\text { Basin }\end{array}$ & Jiwen & 4880 & 522.17 & -0.65 & 83.21 & $1961-2018$ \\
\hline 3 & $\begin{array}{c}\text { Songhua River } \\
\text { Basin }\end{array}$ & Wuerqihan & 3450 & 361.93 & -2.39 & 52.82 & $1960-2018$ \\
\hline 4 & $\begin{array}{c}\text { Songhua River } \\
\text { Basin }\end{array}$ & Hailar & 22516 & 347.11 & -1.08 & 28.02 & $1956-2018$ \\
\hline 5 & $\begin{array}{l}\text { Songhua River } \\
\text { Basin }\end{array}$ & Chaersen & 7827 & 427.96 & 5.03 & 32.32 & $1956-2018$ \\
\hline 6 & $\begin{array}{l}\text { Liaohe River } \\
\text { Basin }\end{array}$ & Baiyinwula & 2866 & 363.38 & 5.02 & 91.66 & $1972-2018$ \\
\hline 7 & $\begin{array}{l}\text { Rivers in } \\
\text { Northwest China }\end{array}$ & Xilinhot & 3852 & 242.68 & 1.92 & 47.73 & $1972-2018$ \\
\hline 8 & $\begin{array}{l}\text { Rivers in } \\
\text { Northwest China }\end{array}$ & Meilinmiao & 18361 & 381.59 & 6.66 & 20.48 & $1956-2018$ \\
\hline 9 & $\begin{array}{l}\text { Rivers in } \\
\text { Northwest China }\end{array}$ & Jining & 701 & 364.84 & 4.33 & 18.7 & $1956-2018$ \\
\hline 10 & $\begin{array}{l}\text { Yellow River } \\
\text { Basin }\end{array}$ & Halaqin & 706 & 414.15 & 6.76 & 28.96 & $1956-2018$ \\
\hline 11 & $\begin{array}{l}\text { Heihe River } \\
\text { Basin }\end{array}$ & Yingluoxia & 10009 & 411.06 & 1.16 & 63.66 & $1957-2018$ \\
\hline 12 & $\begin{array}{l}\text { Heihe River } \\
\text { Basin }\end{array}$ & Zhengyixia & 35634 & 108.21 & 7.95 & 11.25 & $1957-2018$ \\
\hline
\end{tabular}

\subsection{Data processing and methods}

(1) For the consistency of the temperature time series, the missing measurement data were interpolated and extended by correlation and regression analysis (Wang et al., 2013).

(2) For the meteorological data of the catchment area corresponding to the runoff stations, the inverse distance weighting method was used to spatially interpolate the precipitation, temperature, and evaporation, and each meteorological factor was extracted onto a $100 \mathrm{~m} \times 100 \mathrm{~m}$ grid. Then the Zonal Histogram tool in ArcGIS was used to extract the surface average of each meteorological factor corresponding to each basin.

(3) The Mann-Kendall nonparametric statistical method was used to test the abrupt changes in the temperature and runoff (Wang et al., 2007).

(4) Based on a previous study (Fyfe et al., 2016), the year of the WH after the ATC was determined through an analysis using the temperature series and its phased trend line in conjunction with the 3-5-year moving value series and its phased trend line. The WH year was determined to be the year when the climate tendency rate reached a relative maximum after the ATC until the end of the series (2018) or to a certain earlier year and when the climate tendency rate was less than or equal to $0.1^{\circ} \mathrm{C} / 10 \mathrm{a}$. 
(5) The tendency rate method was used for the time series trend analysis of temperature and runoff.

(6) The attribution of the runoff changes was quantitatively identified by a relevant method based on hydrological simulations, which included three parts:

The Mann-Kendall (M-K) nonparametric statistical method is an effective method for diagnosing series variations (abrupt changes) and has been widely used to analyse variations (abrupt changes) in hydrological and meteorological series (Zhang et al., 2020).

Water simulation model. The RCCC-WBM water balance model developed by the Research Center for Climate Change of the Ministry of Water Resources of China was used to simulate the natural runoff process in the basin. This large-scale hydrological model has the advantages of a simple structure, a small number of parameters, and low data requirements, and it is easy to understand. The model is based on a monthly time scale, its inputs include monthly precipitation, water surface evaporation, and temperature, and the simulated runoff includes three components: surface runoff, subsurface runoff, and snowmelt runoff (Bao et al., 2021). For a small-scale basin, this model can be used for lumped simulations of the hydrological process based on the average meteorological factors of the basin. For a medium- or large-scale basin, the model can divide the study basin into grid points for distributed simulations of the hydrological process (Wang et al., 2014). The Nash-Sutcliffe model efficiency coefficient (ENS) and the relative error (ER) of the simulated total runoff were selected as the objective functions for model parameter optimization (Nash et al., 1970).

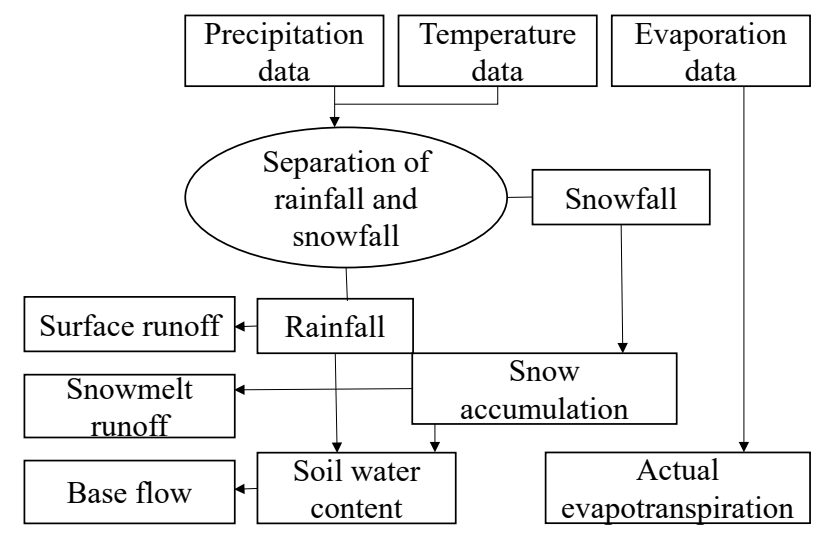

Figure 2 Structure of the RCCC-WBM model

Cause analysis model. The hydrological model parameters were calibrated using the hydrological data prior to human disturbance (a period assumed to have no or insignificant human activity, referred to as the "natural base period"), and the meteorological data series after human disturbance (a period after the abrupt change point, referred to as the "significant period of human activity") and the model parameters calibrated by the data of the natural base period were used to 
simulate the runoff process in the "significant period of human activity." The total runoff changes before and after the abrupt change point in the hydrological series consist of two parts: the impact of climate change and the impact of human activities. The difference in natural runoff before and after the abrupt change point is caused by climate change, while the difference between the measured runoff during the significant period of human activity and the simulated natural runoff (calculated using the calibrated parameters of the natural base period) is the amount of influence of human activities. Therefore, the two key aspects of the quantitative identification method for the attribution of runoff changes are the diagnosis of abrupt changes in runoff (i.e., the identification of the natural base period and the significant period of human activity) and the simulation of natural runoff (Wang et al., 2014). The quantitative identification model for the attribution of runoff changes is as follows:

$$
\begin{gathered}
\Delta W_{T}=W_{H R}-W_{B} \\
\Delta W_{H}=W_{H R}-W_{H N} \\
\Delta W_{C}=W_{H N}-W_{B} \\
\varepsilon_{H}=\frac{\Delta W_{H}}{\Delta W_{T}} \times 100 \% \\
\varepsilon_{C}=\frac{\Delta W_{C}}{\Delta W_{T}} \times 100 \%
\end{gathered}
$$

where $\Delta W_{T}$ is the total change in runoff; $\Delta W_{H}$ and $\Delta W_{C}$ are the runoff changes caused by human activities and climate change, respectively; $W_{B}$ is the runoff in the base period; $W_{H R}$ and $W_{H N}$ are the measured and simulated runoffs in the significant period of human activities, respectively; and $\varepsilon_{H}$ and $\varepsilon_{C}$ are the contributions of human activities and climate change to runoff change, respectively.

(7) The degree of the impacts of the ATC and the WH on runoff were quantitatively analysed by principal component analysis (PCA).

\section{Results and discussion}

\subsection{Multiyear runoff change trends}

Figure 3 shows the measured annual runoff process at each representative station in the midand-low-latitude regions of the temperate continental-monsoon transition zone from the establishment of the stations to 2018. The multiyear runoff significantly increased at the Yingluoxia station only (with a linear tendency rate of annual runoff of $3.362 \mathrm{~mm} / \mathrm{a}$ ) and decreased at the rest of stations. In particular, the measured multiyear runoff did not notably decline at the Mangui, Jiwen, Wuerqihan, Baiyinwula and Zhengyixia stations, but the annual runoff was close to zero after 2003 at the Chaersen, Meilinmiao, and Halaqin stations. 


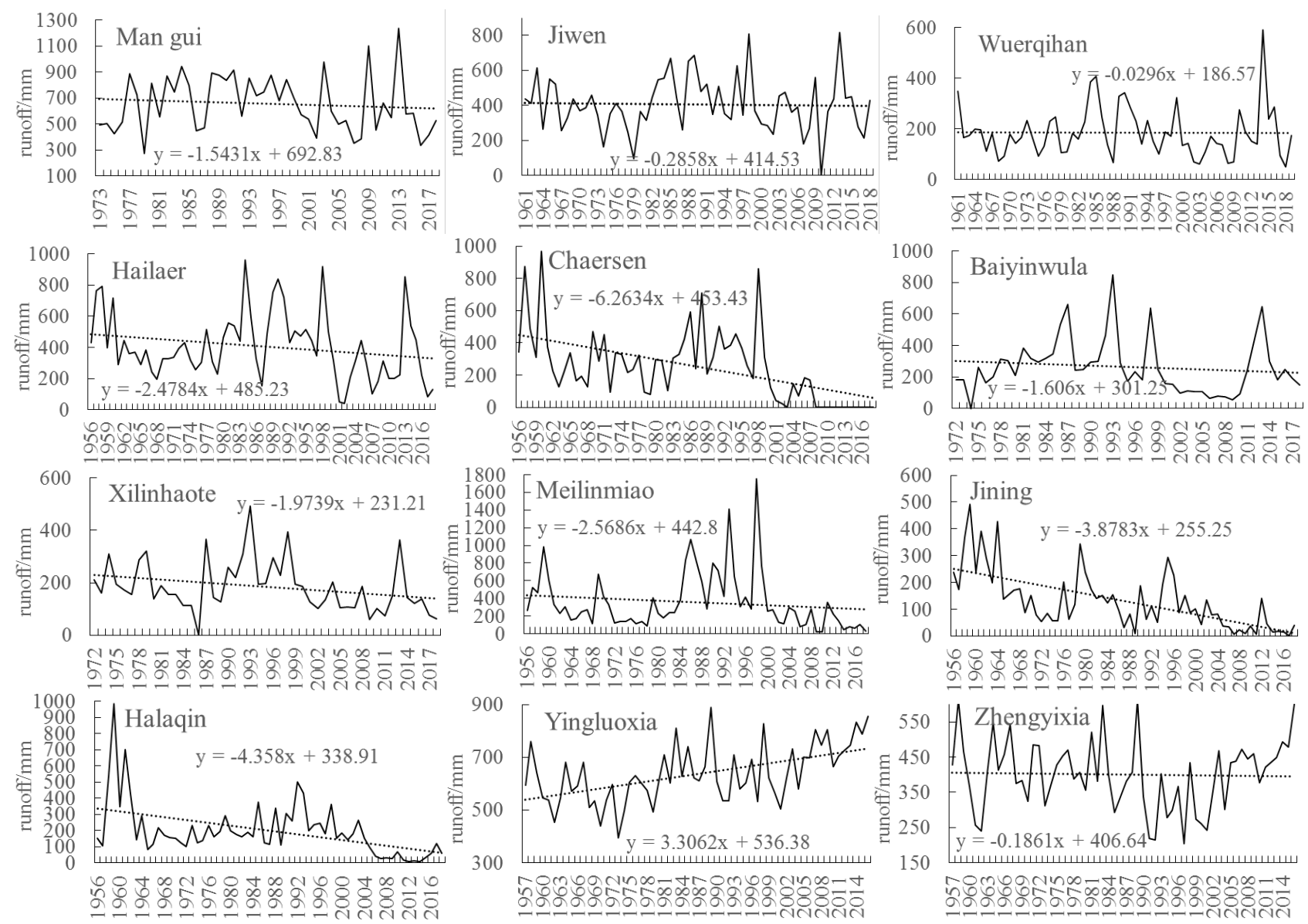

Figure 3 Multiyear runoff changes at representative stations

Table 2 Diagnosis results of abrupt changes in annual runoff at representative hydrological stations

\begin{tabular}{|c|c|c|c|c|c|c|c|}
\hline ID & River & $\begin{array}{l}\text { Hydrological } \\
\text { station }\end{array}$ & $\begin{array}{l}\text { Abrupt } \\
\text { change year }\end{array}$ & $\begin{array}{c}\text { Serial } \\
\text { number }\end{array}$ & River & $\begin{array}{l}\text { Hydrological } \\
\text { station }\end{array}$ & $\begin{array}{l}\text { Abrupt } \\
\text { change year }\end{array}$ \\
\hline
\end{tabular}




\begin{tabular}{|c|c|c|c|c|c|c|c|c|c|}
\hline 1 & $\begin{array}{l}\text { Songhua } \\
\text { Basin }\end{array}$ & River & Mangui & None & 7 & $\begin{array}{l}\text { Rivers } \\
\text { Northwes } \\
\text { China }\end{array}$ & in & Xilinhot & 1998 \\
\hline 2 & $\begin{array}{l}\text { Songhua } \\
\text { Basin }\end{array}$ & River & Jiwen & None & 8 & $\begin{array}{l}\text { Rivers } \\
\text { Northwes } \\
\text { China }\end{array}$ & in & Meilinmiao & 1998 \\
\hline 3 & $\begin{array}{l}\text { Songhua } \\
\text { Basin }\end{array}$ & River & Wuerqihan & None & 9 & $\begin{array}{l}\text { Rivers } \\
\text { Northwes } \\
\text { China }\end{array}$ & in & Jining & 1995 \\
\hline 4 & $\begin{array}{l}\text { Songhua } \\
\text { Basin }\end{array}$ & River & Hailar & 1990 & 10 & $\begin{array}{l}\text { Yellow } \\
\text { Basin }\end{array}$ & River & Halaqin & 1993 \\
\hline 5 & $\begin{array}{l}\text { Songhua } \\
\text { Basin }\end{array}$ & River & Chaersen & 1998 & 11 & $\begin{array}{l}\text { Heihe } \\
\text { Basin }\end{array}$ & River & Yingluoxia & None \\
\hline 6 & $\begin{array}{l}\text { Liaohe } \\
\text { Basin }\end{array}$ & River & Baiyinwula & 1993 & 12 & $\begin{array}{l}\text { Heihe } \\
\text { Basin }\end{array}$ & River & Zhengyixia & None \\
\hline
\end{tabular}

2.2.2 Calibration of model parameters and simulation of natural runoff processes

Model parameter calibration and model validation were performed using the data series prior to the year of the abrupt change in runoff. Table 3 provides the simulation results of monthly flow in the basins of the study area. The ENS values for both the calibration period and the validation period of each basin are above 0.6 , and the ER value of the simulated total runoff is also small and between $\pm 5 \%$. Figure 4 shows the measured and simulated monthly flow processes at the Hailar and Chaershen stations before the abrupt change in runoff, revealing the overall good fit between the two. Table 3 and Figure 4 show that the RCCC-WBM model well simulated the hydrological process of each basin, with a simulation accuracy that meets the requirements. Therefore, this model can be used to simulate the natural runoff process at each station during periods of significant human activity.

Table 3 Simulation results of monthly runoff data for representative hydrological stations

\begin{tabular}{|c|c|c|c|c|c|c|c|}
\hline \multirow{2}{*}{ Basin } & \multirow{2}{*}{$\begin{array}{l}\text { Hydrological } \\
\text { station }\end{array}$} & \multicolumn{3}{|c|}{ Calibration period } & \multicolumn{3}{|c|}{ Validation period } \\
\hline & & Data series & $\mathrm{E}_{\mathrm{NS}}(\%)$ & $E_{R}(\%)$ & Data series & $\mathrm{E}_{\mathrm{NS}}(\%)$ & $E_{R}(\%)$ \\
\hline $\begin{array}{c}\text { Songhua } \\
\text { River Basin }\end{array}$ & Hailar & $1956-1985$ & 64.10 & 3.33 & 1986-1990 & 72.08 & 4.21 \\
\hline $\begin{array}{c}\text { Songhua } \\
\text { River Basin }\end{array}$ & Chaersen & 1956-1990 & 84.71 & 2.54 & 1991-1998 & 73 & 3.43 \\
\hline $\begin{array}{c}\text { Liaohe River } \\
\text { Basin }\end{array}$ & Baiyinwula & $1972-1986$ & 76.91 & 1.35 & 1986-1993 & 81.44 & 2.54 \\
\hline $\begin{array}{l}\text { Rivers in } \\
\text { Northwest } \\
\text { China }\end{array}$ & Xilinhot & $1972-1993$ & 56.9 & 0.85 & 1994-1998 & 69.12 & 1.007 \\
\hline $\begin{array}{l}\text { Rivers in } \\
\text { Northwest } \\
\text { China }\end{array}$ & Meilinmiao & $1972-1993$ & 74.34 & 0.76 & 1994-1998 & 77.98 & 1.54 \\
\hline $\begin{array}{c}\text { Rivers in } \\
\text { Northwest } \\
\text { China }\end{array}$ & Jining & 1956-1990 & 69.43 & 1.34 & 1991-1995 & 75.34 & 2.43 \\
\hline $\begin{array}{c}\text { Yellow } \\
\text { River Basin }\end{array}$ & Halaqin & $1956-1985$ & 77.11 & 1.45 & 1986-1993 & 78.24 & 2.22 \\
\hline
\end{tabular}



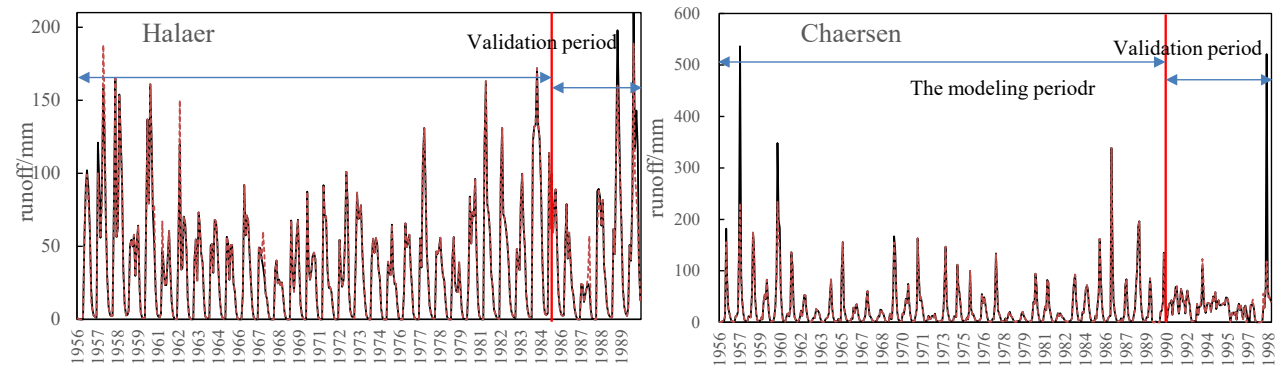

Figure 4 Measured and simulated monthly flows before the abrupt change in runoff at the Hailar and Chaershen stations

The runoff from the establishment of the stations to 2018 in each basin was simulated using the model parameters calibrated by the runoff series before the abrupt change, which can be considered the "natural runoff" of the basin. Figure 5 shows the measured and simulated annual runoffs at the Chaershen and Jining stations, respectively, from station establishment to 2018. For each station, the simulated runoff generally agrees well with the measured runoff before the abrupt change year of the series, but the simulated runoff is significantly larger than the measured runoff after the abrupt change year, indicating that the measured river runoffs at some stations decreased due to the impact of human activities, but the degree of these impacts was spatially variable.
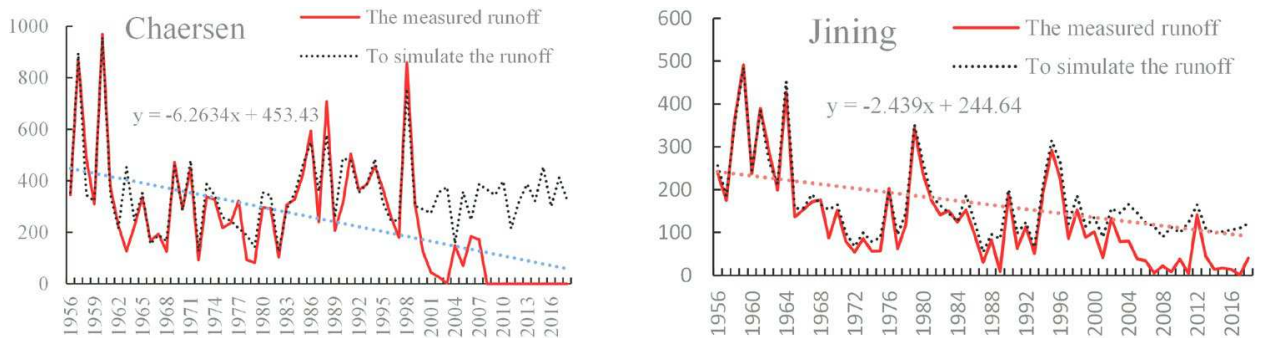

Figure 5 Measured and simulated annual runoff processes at the Chaershen and Jining stations from the establishment of the stations to 2018

\subsubsection{Impact of the ATC and the WH on runoff changes}

Among the runoff stations in the mid-and-low-latitude regions of the temperate continentalmonsoon transition zone, the measured runoffs at five stations, including the Mangui station, did not have obvious abrupt changes from the establishment of the stations to 2018 and were only slightly affected by human activities. Table 5 shows the years of the ATC and the WH at each runoff station and their quantitative impacts on runoff. Overall, the three runoff stations located in the northeastern part of the study area, namely, the Mangui, Jiwen, and Wuerqihan stations, were only slightly impacted by human activities; their average temperatures abruptly increased in 1990, 1987, and 1990, respectively; the average temperatures of the Jiwen and Wuerqihan stations underwent a WH in 2007, while that of the Mangui station did not experience a WH. Further, the impacts of temperature, precipitation, and evaporation on runoff during climate change were separated by PCA. The measured runoff decreased by $2.21 \mathrm{~mm}-13.12 \mathrm{~mm}$ around the ATC; the contributions of precipitation, 
evaporation, and temperature to runoff changes ranged from 72.34-75.77\%, 15.2-17.56\%, and 9.03$13.46 \%$, respectively, before the abrupt change, from $65.75-71.58 \%, 16.55-20.15 \%$, and $13.1-14.1 \%$, respectively, after the abrupt change (before the WH), with a slight increase in the impacts of temperature and evaporation on runoff, and from $71.44-73.52 \%, 16.23-16.55 \%$, and $9.93-12.33 \%$, respectively, after the WH. When an ATC occurred, the average temperature increased by 0.75 $1.43{ }^{\circ} \mathrm{C}$, which increased the runoff by $1.93-2.98 \mathrm{~mm}$; when a $\mathrm{WH}$ occurred, the average temperature increased/decreased by $0.59^{\circ} \mathrm{C}$ and $0.13^{\circ} \mathrm{C}$, which decreased the runoff by $0.13-0.16 \mathrm{~mm}$. Therefore, the impact of the ATC on runoff was greater than the impact of the WH on runoff; in addition, the ATC had a positive driving effect on runoff, while the WH had a negative driving effect on runoff at the stations in the northeastern part of the study area.

In addition, the Yingluoxia and Zhengyixia stations located in the western part of the study area were only slightly impacted by human activities. At the Yingluoxia station, the measured multiyear runoff increased slightly, and there was no obvious abrupt change point in the runoff, which was only slightly impacted by human activities; the average temperature changed abruptly in 1996, after which there was a relative increase of $9.87 \mathrm{~mm}$ in the runoff; the contributions of precipitation, evaporation, and temperature to the runoff changes were $74.68 \%, 13.31 \%$, and $12.01 \%$, respectively, before the ATC, and $71.83 \%, 14.11 \%$ and $14.06 \%$, respectively, after the ATC; the temperature increased by $1.18^{\circ} \mathrm{C}$ after the ATC, leading to an increase in runoff by $3.86 \mathrm{~mm}$; the ATC had a relatively large impact on runoff, which was due to the melting of glaciers in the Qilian Mountains caused by the significant temperature increase and resulted in an increase in runoff. At the Zhengyixia station, the measured multiyear runoff declined slightly, and there was no notable abrupt change point in the runoff, which was only slightly impacted by human activities. The average temperature changed abruptly in 2002, before and after which the impact of the average temperature on runoff was quantified. After the ATC, there was a relative increase of $2.67 \mathrm{~mm}$ in runoff; the contributions of precipitation, evaporation, and temperature to the runoff changes were $72.51 \%, 14.29 \%$, and $13.2 \%$, respectively, before the ATC, and $70.11 \%, 15.22 \%$, and $14.67 \%$, respectively, after the ATC; evaporation at the Zhengyixia station reached the maximum in 1965 and then significantly decreased, and the decrease in evaporation weakened the negative drive on runoff; the temperature increased by $1.08^{\circ} \mathrm{C}$ after the ATC, leading to an increase in runoff of $0.45 \mathrm{~mm}$. The evaporation at the Zhengyixia station reached its maximum in 1965 and subsequently declined significantly. The decrease in evaporation weakened the negative driving effect on runoff, the temperature increased by $1.08{ }^{\circ} \mathrm{C}$ after an abrupt change, and the runoff increased by $0.45 \mathrm{~mm}$. 


\begin{tabular}{|c|c|c|c|c|c|c|c|}
\hline $\begin{array}{l}\text { Hydrological } \\
\text { station }\end{array}$ & $\begin{array}{c}\text { Year } \\
\text { of ATC }\end{array}$ & $\begin{array}{l}\text { Year of } \\
\text { WH }\end{array}$ & $\begin{array}{c}\text { Runoff } \\
\text { before } \\
\text { ATC }(\mathrm{mm})\end{array}$ & $\begin{array}{l}\text { Runoff from } \\
\text { ATC to } \\
\text { WH/runoff } \\
\text { after ATC } \\
\text { (mm) }\end{array}$ & $\begin{array}{l}\text { Runoff } \\
\text { after WH } \\
\text { (mm) }\end{array}$ & $\begin{array}{l}\text { Impact of } \\
\text { ATC on } \\
\text { runoff }(\mathrm{mm})\end{array}$ & $\begin{array}{c}\text { Impact of } \\
\text { WH on runoff } \\
(\mathrm{mm})\end{array}$ \\
\hline Mangui & 1990 & & 86.88 & 80.57 & & -1.95 & \\
\hline Jiwen & 1987 & 2007 & 92.18 & 88.97 & 80.55 & -1.93 & -0.16 \\
\hline Wuerqihan & 1990 & 2007 & 57.17 & 43.97 & 50.71 & -2.98 & -0.13 \\
\hline Hailar & 1990 & 2007 & 19.87 & 20.76 & 18.18 & 0.41 & -5.09 \\
\hline Chaersen & 1990 & 2007 & 44.79 & 45.17 & 44.63 & 0.27 & -0.28 \\
\hline Baiyinwula & 1988 & 2007 & 95.57 & 100.85 & 69.72 & 1.21 & -0.22 \\
\hline Xilinhot & 1994 & & 56.5 & 52.35 & & -0.39 & \\
\hline Meilinmiao & 1991 & 2007 & 22.76 & 30.65 & 15.99 & 4.74 & -0.68 \\
\hline Jining & 1990 & 2007 & 27.25 & 21.58 & 16.05 & -0.41 & -0.59 \\
\hline Halaqin & 1985 & 2007 & 36.81 & 38.55 & 19.74 & & -2.33 \\
\hline Yingluoxia & 1996 & & 60.36 & 70.23 & & 3.86 & \\
\hline Zhengyixia & 2002 & & 10.33 & 13.09 & & 0.45 & \\
\hline
\end{tabular}

Table 4 presents the quantitative identification results of the attribution of runoff changes at the stations impacted by human activities. For each of the stations greatly impacted by human activities, the natural runoff during the entire period was simulated using the period before the abrupt change in runoff as a reference period to further analyse the impacts of ATCs and WHs, among the climate impact factors, on runoff. The seven stations located in the middle of the study area were all highly impacted by human activities, which were responsible for $50-70 \%$ of the runoff and had a negative driving effect on runoff in the study area. The entire series of natural runoff was simulated to quantify the impacts of ATCs and WHs on the runoff at each station.

Table 5 Impacts of climate change and human activities on runoff

\begin{tabular}{|c|c|c|c|c|c|c|c|c|c|}
\hline \multirow[b]{2}{*}{ Basin } & \multirow[b]{2}{*}{$\begin{array}{l}\text { Hydrolog } \\
\text { ical } \\
\text { station }\end{array}$} & \multirow[b]{2}{*}{ Time period } & \multirow[b]{2}{*}{$\begin{array}{c}\text { Measur } \\
\text { ed } \\
\text { runoff } \\
(\mathrm{mm})\end{array}$} & \multirow[b]{2}{*}{$\begin{array}{c}\text { Natural } \\
\text { runoff } \\
(\mathrm{mm})\end{array}$} & \multirow[b]{2}{*}{$\begin{array}{c}\text { Total } \\
\text { chang } \\
\text { e } \\
(\mathrm{mm})\end{array}$} & \multicolumn{2}{|c|}{$\begin{array}{c}\text { Impact of human } \\
\text { activities }\end{array}$} & \multicolumn{2}{|c|}{$\begin{array}{c}\text { Impact of climate } \\
\text { change }\end{array}$} \\
\hline & & & & & & $\begin{array}{c}\text { Absolut } \\
\text { e } \\
\text { impact } \\
(\mathrm{mm})\end{array}$ & $\begin{array}{c}\text { Relativ } \\
\text { e } \\
\text { impact } \\
(\%)\end{array}$ & $\begin{array}{l}\text { Absolut } \\
\text { e } \\
\text { impact } \\
(\mathrm{mm})\end{array}$ & $\begin{array}{c}\text { Relativ } \\
\text { e } \\
\text { impact } \\
(\%)\end{array}$ \\
\hline $\begin{array}{l}\text { Songhua } \\
\text { River } \\
\text { Basin }\end{array}$ & Hailar & $\begin{array}{l}1956-1990 \\
1991-2018\end{array}$ & $\begin{array}{l}19.86 \\
16.06\end{array}$ & 18.27 & -3.8 & -1.93 & 50.81 & -1.87 & 49.19 \\
\hline $\begin{array}{c}\text { Songhua } \\
\text { River } \\
\text { Basin }\end{array}$ & Chaersen & $\begin{array}{l}1956-1998 \\
1999-2018\end{array}$ & $\begin{array}{c}44.14 \\
0.0068\end{array}$ & 44.95 & 44.13 & -32.14 & 72.82 & -11.99 & 27.18 \\
\hline $\begin{array}{l}\text { Liaohe } \\
\text { River } \\
\text { Basin }\end{array}$ & $\begin{array}{l}\text { Baiyinw } \\
\text { ula }\end{array}$ & $\begin{array}{l}1972-1993 \\
1994-2018\end{array}$ & $\begin{array}{c}11.78 \\
7.36\end{array}$ & 8.3 & -4.42 & -3.12 & 70.53 & -1.3 & 29.49 \\
\hline $\begin{array}{c}\text { Rivers in } \\
\text { Northwest } \\
\text { China }\end{array}$ & Xilinhot & $\begin{array}{l}1972-1998 \\
1999-2018\end{array}$ & $\begin{array}{l}60.51 \\
35.59\end{array}$ & 47.4 & 24.92 & -13.21 & 53 & -11.71 & 47 \\
\hline $\begin{array}{c}\text { Rivers in } \\
\text { Northwest } \\
\text { China }\end{array}$ & $\begin{array}{l}\text { Meilinmi } \\
\text { ao }\end{array}$ & $\begin{array}{l}1972-1998 \\
1999-2018\end{array}$ & $\begin{array}{c}24.13 \\
9.98\end{array}$ & 17.68 & 14.15 & -7.7 & 54.44 & -6.45 & 45.56 \\
\hline $\begin{array}{c}\text { Rivers in } \\
\text { Northwest } \\
\text { China }\end{array}$ & Jining & $\begin{array}{l}1956-1995 \\
1996-2018\end{array}$ & $\begin{array}{c}24.43 \\
8.76\end{array}$ & 18.58 & $\begin{array}{c}- \\
15.67\end{array}$ & -9.83 & 62.71 & -5.84 & 37.27 \\
\hline
\end{tabular}




\begin{tabular}{|c|c|c|c|c|c|c|c|c|c|}
\hline $\begin{array}{l}\text { Yellow } \\
\text { River } \\
\text { Basin }\end{array}$ & Halaqin & $\begin{array}{l}1956-1993 \\
1994-2018\end{array}$ & $\begin{array}{l}37.15 \\
16.51\end{array}$ & 27.52 & $\begin{array}{c}- \\
20.64\end{array}$ & -11.01 & 53.35 & -9.63 & 46.65 \\
\hline
\end{tabular}

The average temperature of each basin experienced an abrupt increase from the late 1980 s to the early 1990s, and a WH occurred at all stations in 2007 except for the Xilinhot station. Around the ATC, the runoff at most stations increased, while the runoff at the Xilinhot and Jining stations decreased; after that, the runoff at all stations decreased until around the WH. The contributions of precipitation, evaporation, and average temperature to the runoff changes ranged from $66.24-75.22 \%$, 13.58-20.56\%, and 11.2-14.2\%, respectively, before the ATC, and from $65.57-71.59 \%, 15.4-19.35 \%$, and 13.63-16.34\%, respectively, after the ATC (before the WH); after the ATC, the impacts on runoff increased slightly; and after the $\mathrm{WH}$, the contributions of precipitation, evaporation, and temperature to the runoff changes ranged from $66.94-70.63 \%, 15.42-20.66 \%$, and $8.71-15.33 \%$, respectively. When the ATC occurred, the average temperature increased by $0.89-1.75{ }^{\circ} \mathrm{C}$, leading to an increase of $0.27-11.74 \mathrm{~mm}$ in runoff, and the runoff at the Xilinhot and Jining stations decreased by $0.39 \mathrm{~mm}$ and $0.41 \mathrm{~mm}$, respectively; when the WH occurred, the average temperature increased/decreased by 0.005- $0.15^{\circ} \mathrm{C}$, resulting in a decrease of $0.28-15.22 \mathrm{~mm}$ in runoff. Therefore, the ATC in the middle of the study area had both positive and negative driving effects on runoff, while the WH led to a slight decrease in runoff.

\section{Conclusion and discussion}

The global climate has changed significantly in the past 100 years, and the rapid development of human society has led to changes in the underlying surface and the construction of hydraulic projects, significantly impacting natural hydrological processes (Yin et al., 2018). In this study, the impacts of climate change and human activities on the measured runoff at 12 representative runoff stations in the mid-and-low-latitude regions of the temperate continental-monsoon transition zone were quantitatively evaluated using the WBM model system. The results show that the runoff in the study area decreased overall; in particular, the runoff at five sites in the northeastern and western parts of the study area were essentially not impacted by human activities, while the runoff at seven stations in the central part of the study area were substantially impacted by human activities, with a maximum degree of impact of more than 70\%. The impacts of ATCs and WHs on runoff were further analysed quantitatively. The average temperature of each basin in the study area underwent a significant abrupt temperature increase in the 1990s, and the Mangui, Jiwen, and Wuerqihan stations in the northeastern part of the study area were largely not impacted by human activities; after the ATC, evaporation increased but precipitation levels remained stable; and the abrupt temperature increase had a negative driving effect on runoff, which was reduced by $1.92-2.98 \mathrm{~mm}$. The runoff between the Hailar and 
Halaqin stations in the central part of the study area was remarkably impacted by human activities, with a maximum degree of impact of more than $70 \%$. After removing the impact of human activities, evaporation declined after the abrupt temperature increase; i.e., the "evaporation paradox" phenomenon appeared in these regions (Liu et al., 2009). During this period, precipitation levels remained stable, and the ATC increased the runoff depth by 0.27-4.74 $\mathrm{mm}$. The Yingluoxia and Zhengyixia stations in the western part of the study area are located near the Qilian Mountains, and their runoff changes were only slightly impacted by human activities. Due to snowmelt, the runoff increased significantly to $3.86 \mathrm{~mm}$ after the ATC. In 2007, the average temperature of some basins experienced a WH, which had a relatively small and negative driving effect on runoff. This result may have occurred because even with the WH, the temperature was still high before the WH, reducing the runoff by $0.13-0.59 \mathrm{~mm}$ under the condition of small changes in precipitation and evaporation. In terms of the contributions to the runoff changes before and after the ATCs and the WH, the contribution of temperature to the runoff changes was slightly greater after the ATC than that before the ATC, indicating that the abrupt and drastic change in temperature led to an increase in the impact on runoff, but there was no obvious pattern in the contribution after the WH. Overall, most of the runoff stations in the mid-and-low-latitude regions of the temperate continental-monsoon transition zone were significantly impacted by human activities after the 1990s; in terms of climate factors, the runoff was most related to and greatly impacted by precipitation, while the impacts of the ATCs and the WH on runoff were relatively small; regardless, these impacts deserve attention. Precipitation and temperature have been shown to impact runoff changes at the Zhengyixia station (Li, 2020), similar to the findings of our study, which reveals that the ATCs also had a large impact on the runoff at the Yingluoxia station. Previous studies have mostly focused on the impact of climate change on runoff. In terms of multiyear changes in the measured runoff, that of the Pearl and Yangtze Rivers in southern China is dominated by natural fluctuations and not significantly impacted by human activities, while that of the rivers in northern China significantly decreases (Zhang et al., 2020). Climate change impacts runoff through changes in climatic conditions such as precipitation and temperature. The elasticity coefficients of runoff changes to various meteorological factors and underlying surface factors are significantly higher in the basins in North China, which have a relatively dry climate, compared to those in South China, which have a relatively humid climate, and the runoff changes in North China are more sensitive to climate change than those in South China (Liu et al., 2016).

The runoff in the mid-and-low-latitude regions of the temperate continental-monsoon transition zone is impacted by human activities. As a result, the underlying surface of the basins has changed, and human and natural consumption of water resources has increased significantly, leading to increased vulnerability of water resources in the basins (Haddeland et al. 2014). In addition, ATCs 
and WHs have also contributed to changes in the water resources in the basins. In this study, only precipitation, evaporation, and temperature data were used, and there are certain limitations in the selection of meteorological factors. In future studies, more meteorological factors should be added to evaluate the impacts of ATCs and WHs on runoff.

\section{Author Declarations}

The Data Availability Statement: The temperature data used or created in this study can be downloaded from the China National Meteorological Website. http://data.cma.cn/

Funding: This study was financially supported by the National Natural Science Foundation of China under grant Nos. 51869016. Natural Science Foundation of Inner Mongolia Autonomous Region Nos. 2020MS05054. Inner Mongolia Autonomous Region "Grassland talents" project.

Conflicts of Interest: The authors declare no conflict of interest.

Ethics approval/declarations: All co-authors agree to approve

Consent to participate: All co-authors agreed to participate

Consent for publication: All co-authors agreed to publish

Authors' contributions: $\mathrm{XH}$ was responsible for the writing, modification and data processing of the paper, LM was responsible for the overall idea of the paper, TL was responsible for the overall idea of the paper, BS, YC, ZQ was responsible for processing part of the data

\section{Reference}

Bao Zhengxin, Zhang Jianyun, Yan Xiaolin, Wang Guoqing, He Ruimin, Guan Tiesheng, Liu Yanli. 2021. Quantitative assessment of the attribution of runoff change caused by four factors in the Haihe R iver basin, ADVANCES IN WATE R SCIENCE, 32(2): 171-181. DOI: 10. 14042 /j. cnki. 32. 1309. 2021. 02.002.

Chao Zhang, Shuanglin Li, Feifei Luo, Zhen Huang. 2019. The global warming hiatus has faded away: An analysis of 2014-2016 global surface air temperatures, International journal of climatology, 39:4853-4868.

CHEN L H, LIU W F, LENG G, et al. 2018. Study on interannual and seasonal variation characteristics of runoff in the main stream of the Xijiang R iver. South-to-North Water Transfers and Water Science \& Technology, 16(4): 74-82.

DAI A, QIAN T, TRENBERTH K E, et al. 2009. Changes in continental freshwater discharge from 1948 to 2004. Journal of Climate, 22(10):2773-2792.

Fang Hongyang, Yuan Zhe, Yan Denghua. 2014. Study on attribution of runoff evolution of Yellow R iver. Water Resources and Hydropower Engineering, (4): 1-6.

Fyfe, J.C., Meehl, G.A., England, M.H., Mann, M.E., Santer, B.D., Flato, G.M., Hawkins, E., Gillett, N.P., Xie, S.P., Kosaka, Y. 2016. Making sense of the early-2000s warming slow-down. Nat. Clim. Chang. 6, 224-228, doi: 10.1038/nclimate2938.

Haddeland I, Heinke J, Biemans H, et al. 2014, Global water resources affected by human interventions and climate change. roceedings of the National Academy of Sciences of the United States of America, 111 (9): 3251-3256

Idso S B, Kimball B A, Anderson M G, et al. Effects of atmospheric $\mathrm{CO}<$ sun $>2$ enrichment an plant growth: the interactive role of air temperature. Agriculture, ecosystems environment. 1987, 20(01):1-10.

Jiao Yang, Lei Huimin, Yang Dawen. 2017. Attribution of discharge changes over Wuding River watershed using a distributed ecohydrological model, Journal of Hydroelectric Engineering, Vol. 36, No. 7: 34-44.

Kramer R J, Bounoua L, Zhang P, et al. 2015. Evapotranspiration Trends Over the Eastern United States During the 20th Century. Hydrology, (2): 93-111. 
Labat M M, Foldes G, Kohnova S, et al. 2020. Land use and climate change impact on runoff in a small mountainous catchment in Slovakia. Earth and Environmental Science, 444(1): 12036.

Li Qiuju. 2020. China University of Geosciences (Beijing), (in Chinese)

Liu Jianyu, Zhang Qiang, Chen Xi, Gu Xihui. 2016. Quantitative evaluations of human- and climate-induced impacts on hydrological processes of China. Acta Geographica Sinica, Vol.71, No.11.

Liu Min, Shen Yuanjun, Zheng Yan. 2009. Changing Trend of Pan Evaporation and Its Cause over the Past 50 Years in China. ACTA GEOGRAPHICA SINICA. 64(03):259-269.

Mimikou M A,Balras E, Varanou E, et al.Regional impacts of climate change on water resources quantity and qualtiy indicators, Journal of Hydrology, 2000, 234(01):95-109.

Mu Xia, Liu Qiang, Ping Fan. 2017. Analysis of change in annual stream flow and its influence factors in Wuding River basin in the last 50 years 1960-2007. Journal of Beijing Normal University (Natural Science), (4): 465-471.

Rakhimova M, Liu T, Bissenbayeva S, et al. 2020, Assessment of the Impacts of Climate Change and Human Activities on Runoff Using Climate Elasticity Method and General Circulation Model (GCM) in the Buqtyrma River Basin, Kazakhstan. Sustainability, 12(12): 4968 .

Rakhimova M, Liu T, Bissenbayeva S, et al. 2020. Assessment of the Impacts of Climate Change and Human Activities on Runoff Using Climate Elasticity Method and General Circulation Model (GCM) in the Buqtyrma River Basin, Kazakhstan. Sustainability, 12(12): 4968.

Roudier P, Ducharne A, Feyen L. 2014, Climate change impacts on runoff in West Africa: a review. Hydrology and Earth System Sciences, (7): 2789-2801.

Roudier P, Ducharne A, Feyen L. 2014. Climate change impacts on runoff in West Africa: a review. Hydrology and Earth System Sciences, (7): 2789-2801.

TIAN L, WANG S J. 2018. Analysis of the runoff change and main influencing factors in the Liaohe River basin. R esearch of Soil and WaterConservation, (1): 153-159.

WANG G Q, ZHANG J Y, JIN J L, et al. 2014. Regional calibration of a water balance model for estimating stream flow in ungauged areas of the Yellow River basin. Quaternary International, 336: 65-72.

WANG Guoqing, ZHANG Jianyun, HE Ruimin. 2006. Impact of environmental change on runoff in Fenhe River basin of the middle Yellow River. Advances in Water Science, 17(6): 851-858.

WANG X G, HU J, LYU J, et al. 2017. Variation characteristics of annual runoff in the Songhua R iver basin from 1956 to 2014. Soil and Water Conservation in China, (10):61-65.

WANG X X. 2014. Advances in separating effects of climate variability and human activity on stream discharge: An overview. Advances in Water Resources, 71: 209-218.

Wang, H. Chen, Y. Xun, S. Lai, D. Fan, Y. Li, Z. 2013. Changes in daily climate extremes in the arid area of northwestern China. Theor. Appl. Climatol. 112, 15-28.

Wang, X.L. Wen, Q.H. Wu, Y. 2007. Penalized maximal t test for detecting undocumented mean change in climate data series. J. Appl. Meteorol. Climatol. 46, 916-931, doi:10.1175/ JAM2504.1.

Xing Huang, Long Ma, et al. 2020. Spatial and temporal variability of the abrupt interannual temperature change and warming hiatus in China, 1951-2016. Meteorol Appl. 2020; 27: e1911. https://doi.org/10.1002/met.1911

Yang Dawen, Zhang Shulei, Xu Xiangyu. 2015. Attribution analysis for runoff decline in Yellow River Basin during past fifty years based on Budyko hypothesis, Scientia Sinica (Technologica), (10): 1024-1034.

Yang H, Qi J, Xu X, et al. 2014. The regional variation in climate elasticity and climate contribution to runoff across China.Journal of Hydrology, 517: 607-616.

Yin J B, Gentine P, Zhou S, et al. 2018. Large increase in global storm runoff extremes driven by climate and anthropogenic changes. Nature Communications, 9 (1): 1-10 
ZHANG J Y, WANG G Q, JIN J L, et al. 2020. Evolution and variation characteristics of the recorded runoff for the major riversin China during 1956-2018. Advances in Water Science, 31(2): 153-161.

ZHANG J Y, ZHANG S L, WANG J X, et al. 2007. Study on runoff trends of the six larger basins in China over the past 50 years. Advances in Water Science, 18(2): 230-234.

Zhang Jiangyun, Wang Guoqing, Jin Junliang, He Ruimin, Liu Cuishan. 2020. Evolution and variation characteristics of the recorded runoff for the major rivers in China during 1956-2018. ADVANCES IN WATER SCIENCE, 31(2). DOI: 10. 14042 /j. cnki. 32. 1309. 2020. 02. 001

ZHANG L R, HE Y H, TANG Y P, et al. 2017. Analysis of runoff change trend and its attribution in Haihe River basin. HydroScience and Engineering, (4):59-66.

ZHANG Liru, HE Yonghui, TANG Yueping, et al. 2017. Analysis of runoff change trend and its attribution in Haihe River basin. Hydro-Science and Engineering, (4): 59 - 66.

Zhang Shifeng, Hua Dong, Meng Xiujing, Zhang Yongyong. 2011. Climate change and its driving effect on the runoff in the "ThreeRiver Headwaters" region. Journal of Geographical Sciences, 21(06):963-978.

Zhao G J, Tian P, Mu X M, et al. 2014. Quantifying the impact of climate variability and human activities on streamflow in the middle reaches of the Yellow River basin, China. Journal of Hydrology, 519: 387-398.

ZHAO J H, LIU C S, WANG G Q, et al. 2018. Evolution of stream flow in the Yellow River during the past 60 years and its response to climate change. Journal of North China University of Water Resources and Electric Power ( Natural Science Edition), 39(3): $1-5$.

ZHOU J J, ZHANG M. 2018. Effect of dams on the regime of the mid-lower Yangtze River runoff and countermeasures. Journal of Lake Science, 30(6): 1471-1488. 